\title{
Characterisation of norovirus contamination in an Irish shellfishery using real-time RT-qPCR and sequencing analysis
}

Paulina Rajko-Nenow ${ }^{\mathrm{a}}$, Sinéad Keaveney ${ }^{\mathrm{a}}$, John Flannery ${ }^{\mathrm{a}}$, Vincent O’Flaherty ${ }^{\mathrm{b}}$, and William Doré ${ }^{\mathrm{a}}$

${ }^{a}$ Marine Institute, Rinville, Oranmore, Co. Galway, Ireland

${ }^{b}$ Microbal Ecology Laboratory, Microbiology, School of Natural Sciences, National University of Ireland, Galway, Ireland

Corresponding author:

Paulina Rajko-Nenow

Marine Institute

Rinville

Oranmore

Co. Galway

Ireland

Tel. +353 91387243

Fax. +353 91387201

Email: paulina.rajkonenow@marine.ie 


\section{Abstract}

Norovirus (NoV) is the single most important agent of foodborne viral gastroenteritis worldwide. Bivalve shellfish, such as oysters, grown in areas contaminated with human faecal waste may become contaminated with human pathogens including NoV. A study was undertaken to investigate NoV contamination in oysters (Crassostrea gigas) from a shellfishery over a 24 month period from October 2007 to September 2009. Oyster samples were collected monthly from a commercial shellfish harvest area classified as category B under EU regulations, but that had had been closed for commercial harvesting due to it's previous association with NoV outbreaks. Real-time reverse transcription quantitative PCR (RT-qPCR) was used to determine the concentration of human NoV genogroups I and II (GI and GII) in monthly samples. Total NoV (GI and GII) concentrations in NoV positive oysters ranged from 97 to 20,080 genome copies $\mathrm{g}^{-1}$ of digestive tissue and displayed a strong seasonal trend with greater concentrations occurring during the winter months. While NoV GII concentrations detected in oysters during both years were similar, NoV GI concentrations were significantly greater in oysters during the winter of 2008/09 than during the winter of 2007/08. To examine the NoV genotypes present in oyster samples, sequence analysis of nested RT-PCR products was undertaken. Although NoV GII.4 is responsible for the vast majority of reports of outbreaks in the community, multiple NoV genotypes were identified in oysters during this study: GI.4, GI.3, GI.2, GII.4, GII.b, GII.2, GII.12, and GII.e. NoV GI.4 was the most frequently detected genotype throughout the study period and was detected in $88.9 \%$ of positive samples, this was followed by GII.4 (43.7\%) and GII.b (37.5\%). This data demonstrates the diversity of NoV genotypes that can be present in sewage contaminated shellfish and that a disproportionate number of non 
NoV GII.4 genotypes can be found in environmental samples compared to the number of recorded human infections associated with non NoV GII.4 genotypes.

Keywords: norovirus; oysters; seasonality; multiple genotypes; RT-qPCR 


\section{Introduction}

Bivalve molluscs, such as oysters, are filterfeeding shellfish that can bioaccumulate human pathogenic microorganisms when grown in waters impacted by sewage. Faecally contaminated shellfish represent a risk to human health, especially when consumed raw or lightly cooked (Halliday et al., 1991; Richards, 1985). Norovirus (NoV) is recognised as the most frequent cause of shellfish-associated illness worldwide and has been linked to numerous outbreaks of acute gastroenteritis in consumers (Lees, 2000). Current control measures rely on the use of bacterial indicator organisms such as Escherichia coli (E. coli) to assess the faecal contamination of shellfish (Butt et al., 2004; Lees, 2000). Despite these controls, oysters that are fully compliant with existing bacterial standards continue to be associated with NoV outbreaks in Europe (Baker et al., 2010; Doré et al., 2010; Le Guyader et al., 2010) and elsewhere (David et al., 2007; Huppatz et al., 2008).

In general, NoV gastroenteritis is considered a mild and self-limiting illness, involving diarrhoea and vomiting, with symptoms lasting for 2-3 days (Kaplan et al., 1982). NoV is spread by the faecal-oral route and outbreaks are most often reported in healthcare settings, where they contribute to significant financial costs (Lopman et al., 2004). Although NoV infections in the community occur throughout the year, the annual peak of NoV infection during the winter months can be associated with dry and cold environmental conditions (Lopman et al., 2009).

NoV is one of five genera recognized within the family Caliciviridae, and human NoV contains a positive sense single-stranded RNA genome that is organised into three open reading frames (ORFs). ORF1 encodes non-structural proteins, including the RNAdependent RNA polymerase; ORF2 encodes the major capsid protein; and ORF3 encodes a minor capsid protein (Jiang, 1993). The NoV genome can undergo recombination, which 
occurs relatively frequently at the ORF1/ORF2 junction (Bull et al., 2005). NoV exhibits considerable genetic diversity and has been classified into five distinct genogroups (GIGV) based on phylogenetic analysis of the capsid protein (Zheng et al., 2006). Of the five genogroups NoV GI, NoV GII, and less frequently NoV GIV infect humans and each genogroup is further subdivided into numerous genotypes. NoV GII and, in particular, variants of the NoV GII genotype 4 (GII.4), are most often associated with outbreaks in healthcare and other enclosed settings where person-to-person transmission occurs (Kroneman et al., 2008). NoV GI genotypes have, however, been reported in one study in Sweden as being more frequently implicated in water-related (drinking and recreational) outbreaks than NoV GII (Lysen et al., 2009). Shellfish related outbreaks are often associated with multiple NoV genotypes (GI and GII) that are detected both in contaminated shellfish and faeces of infected individuals (Le Guyader et al., 2006). The detection of NoV in environmental samples relies on molecular techniques that have been developed to overcome a number of issues, such as low target virus concentrations, the presence of inhibitory substances in sample matrices and the diversity of the NoV genome (Le Guyader et al., 2009). Broadly reactive and sensitive real-time quantitative reverse transcription PCR (RT-qPCR) assays that target the conserved ORF1/ORF2 junction of the NoV genome, have been designed for the detection and quantification of NoV GI and GII in shellfish (da Silva et al., 2007; Kageyama et al., 2003; Loisy et al., 2005; Svraka et al., 2007). RT-qPCR procedures have been used successfully in a number of studies to assess the concentrations of NoV in shellfish (Flannery et al., 2012; Kageyama et al., 2003; Loisy et al., 2005; Lowther et al., 2008). More recently, a standardised method based on RT-qPCR detection of NoV and Hepatitis A in food has been developed by the European Committee for Standardisation (CEN) working group (TC 275/WG6/TAG 4 - 
Detection of viruses in food;(Lees et al., 2010) and provides a tool to quantify NoV concentration in shellfish. While this method does not distinguish between infectious and non-infectious virus particles it has been used to demonstrate that the risk of illness associated with oysters increases with increasing concentrations of NoV genome copies present (Lowther et al., 2012). RT-qPCR, therefore, can be a useful tool for assessing the extent of NoV contamination in shellfish which may indicate the potential risk associated with the consumption of such contaminated shellfish.In this study, we used RT-qPCR to investigate the concentrations of NoV in oysters, over a two year period, from a shellfish harvest area that was closed for commercial harvesting because it had been previously associated with outbreaks of NoV illness. We also undertook phylogenetic analysis to establish the profile of NoV genotypes present in the oysters over this time. 


\section{Material and methods}

\subsection{Study site selection}

An oyster harvest area, which was closed for harvesting due to previous incidents of NoV contamination leading to illness outbreaks, was selected for this study. The harvest area may be impacted by a number of wastewater treatment plant discharges (WWTP), including from one that provides UV disinfection in addition to secondary treatment and serves a population equivalent (p.e.) of 10,000, located approximately $1 \mathrm{~km}$ from the harvest area; and another providing secondary treatment only (p.e. of 420,000), located approximately $10 \mathrm{~km}$ from the site.

The selected sampling site was monitored for E. coli levels by the Sea Fisheries Protection Authority (SFPA) as part of the national classification of shellfish harvest area. During the study period the site was consistent with a category B site. Between October 2007 and September 2009, E. coli results for the majority of the samples were $<230$ E.coli $100 \mathrm{~g}^{-1}$ (category A - upper limit) and none of the obtained results was greater than 4,600 E.coli $100 \mathrm{~g}^{-1}$ (category B - upper limit).

\subsection{Shellfish sampling and processing}

Oyster (Crassostrea gigas) samples were collected on a monthly basis $(n=23)$ over a 2-year period, from October 2007 to September 2009, from a single site within the closed harvest area. Sampling was carried out by an SFPA officer and approximately 18 oysters were transported to the Marine Institute laboratory within 48 hours under chilled conditions $\left(<15^{\circ} \mathrm{C}\right)$. Ten alive oysters were cleaned by rinsing under running tap water and opened using a flame sterilised shucking knife. The digestive tissues (DT) of 10 oysters were transferred to a sterile petri dish, weighed and chopped. Per 1 gram of DT, twenty five microlitres of Mengo virus strain $\mathrm{MC}_{0}$ was added as an internal positive control (IPC) virus 
controlling for the virus extraction efficiency (Costafreda et al., 2006) followed by $1 \mathrm{ml}$ of Proteinase K solution (100 $\mu \mathrm{g} \mathrm{ml}^{-1}$; Sigma-Aldrich, Dorset, UK).The sample was then incubated at $37^{\circ} \mathrm{C}$, with shaking, for $60 \mathrm{~min}$ followed by incubation at $60^{\circ} \mathrm{C}$ for $15 \mathrm{~min}$. The sample was centrifuged at $3000 \mathrm{x}$ g for $5 \mathrm{~min}$ and the shellfish proteinase $\mathrm{K}$ extract (supernatant) was stored for a period of less than 1 month, at $-80^{\circ} \mathrm{C}$, prior to RNA extraction.

\subsection{RNA extraction}

Viral RNA was extracted from $500 \mu \mathrm{l}$ of shellfish proteinase K extract using the NucliSENS ${ }^{\circledR}$ miniMAG ${ }^{\circledR}$ extraction platform and NucliSENS ${ }^{\circledR}$ magnetic extraction reagents (bioMérieux, Marcy l'Etoile, France) according to the manufacturer's instructions. A negative RNA extraction control (molecular biology grade water) was included alongside each batch of shellfish sample. Prior to nested RT-PCR, each shellfish sample was extracted at four different dilutions of shellfish proteinase K extract: neat, 1:1.25, 1:2 and 1:5 (dilutions prepared in PBS, Oxoid, Basingstoke, England). Viral RNA was eluted into $100 \mu \mathrm{l}$ of elution buffer and was stored at $-80^{\circ} \mathrm{C}$ until further analysis.

\subsection{RT-qPCR assay}

\subsubsection{Preparation of standards and controls}

Plasmids pGEM-3Zf(+) carrying the GI and GII target sequences containing restriction site (BamH1) to check for contamination (supplied by Dr. Francoise S. LeGuyader, Ifremer, Nantes, France) were transformed into competent cells and transformant clones were screened. Plasmid dsDNA was isolated from bacterial cultures using the GenElute Plasmid 
Miniprep kit (Sigma-Aldrich, Dorset, UK), and then purified using the QIAquick PCR purification kit (Qiagen, West Sussex, UK). The purified plasmids were quantified by spectrophotometry at $260 \mathrm{~nm}$ using a NanoDrop 1000 (Thermo Scientific, Wilmington, DE). For both NoV GI and NoV GII, single-use aliquots containing dsDNA of $10^{5}$ genome copies $\mu \mathrm{l}^{-1}$ were prepared for use as quantification standards. In addition, the purified dsDNA plasmid was linearized, and transcribed in vitro using the Riboprobe transcription system (Promega, UK) for preparation of controls for RT-qPCR inhibition. After DNase treatment, NoV GI and NoV GII external control (EC) RNA were purified and quantified by spectrophotometry at $260 \mathrm{~nm}$. The dsDNA standards and EC RNA controls were stored at $-20^{\circ} \mathrm{C}$.

\subsubsection{Quantification of NoV in shellfish samples}

RT-qPCR was performed using RNA Ultrasense ${ }^{\mathrm{TM}}$ one-step quantitative RT-PCR system (Invitrogen, Carlsbad, CA) on an AB7500 real-time PCR instrument (Applied Biosystems, Foster City, CA). For NoV GI and NoV GII analysis of shellfish samples, $20 \mu \mathrm{l}$ of the appropriate reaction mix containing final concentrations of $1 \mathrm{X}$ reaction mix, $12.5 \mathrm{pmol}$ forward primer, $22.5 \mathrm{pmol}$ reverse primer, 6.25 pmol probe, $1 \mathrm{X}$ Rox and $1.25 \mu \mathrm{l}$ of enzyme mix was added to the designated wells of the 96-well plate. This was followed by duplicate $5 \mu \mathrm{l}$ aliquots of sample RNA or extraction control. Previously described primers and probes were used for separate analysis of NoV GI and GII. For NoV GI forward primer QNIF4 (da Silva et al., 2007), reverse primer NV1LCR, and probe NVGG1p (Svraka et al., 2007) and for NoV GII forward primer QNIF2 (Loisy et al., 2005), reverse primer COG2R (Kageyama et al., 2003), and probe QNIFS (Loisy et al., 2005) were used for the RT-qPCR assays. The reaction plate was incubated for $60 \mathrm{~min}$ at $55^{\circ} \mathrm{C}, 5 \mathrm{~min}$ at $95^{\circ} \mathrm{C}$ with 45 cycles 
of $15 \mathrm{~s}$ at $95^{\circ} \mathrm{C}, 1 \mathrm{~min}$ at $60^{\circ} \mathrm{C}$, and $1 \mathrm{~min}$ at $65^{\circ} \mathrm{C}$. No template controls using molecular biology grade water were included for the NoV GI and the NoV GII assays.

To determine the concentrations of NoV (genome copies $\left.\mathrm{g}^{-1} \mathrm{DT}\right)$, a dilution series $\left(10^{5}\right.$ to $10^{1}$ copies $\mu l^{-1}$ ) of the NoV GI and NoV GII DNA plasmids were included in duplicate on each RT-qPCR run. The number of NoV copies in each positive sample was determined by comparison of the quantification cycle $\left(C_{q}\right)$ value obtained to the standard curves. The final concentration was then adjusted, based on dilution factors, and expressed as detectable virus genome copies $\mathrm{g}^{-1}$ DT. The limit of detection (LOD) for NoV GI and NoV GII was 20 detectable genome copies $\mathrm{g}^{-1}$ DT for shellfish.

To test for the presence of RT-PCR inhibitors, $5 \mu \mathrm{l}$ of sample RNA were added to a further two wells to which $1 \mu \mathrm{l}$ of EC RNA $\left(10^{7}\right.$ genome copies $\left.\mu \mathrm{l}^{-1}\right)$ was added. A log dilution series of the NoV GI and GII EC RNA ranging from $10^{7}$ to $10^{4}$ copies $\mu l^{-1}$ was included on each RT-qPCR run. The mean $C_{q}$ value obtained for samples that included the EC RNA was used to calculate the quantity of EC RNA detected in the sample which was then used to estimate PCR amplification efficiency which was expressed as a percentage. Samples with an amplification efficiency of less than 25\% were not accepted and in such cases the sample's RNA was reanalysed at a 1:10 dilution.

For extraction efficiency, (determined using the IPC; Mengo virus), forward (Mengo209) and reverse (Mengo110) primers and probe (Mengo147) were used as described previously by (Pintó et al., 2009). Twenty microlitres of one-step reaction mix was added to the adjacent wells of the 96-well plate followed by duplicate of $5 \mu$ l aliquots of sample or extraction control RNA. The reaction mix was prepared with the same one-step RT-qPCR system containing the same concentrations of reaction mix, primers, probe, Rox and enzyme mix as was used for NoV analysis. The $C_{T}$ value of the sample was compared to a 
standard curve obtained by preparing log dilutions from the same batch of Mengo virus as was used to seed samples for analysis. This was expressed as percentage extraction efficiency and samples with an extraction efficiency of less than $1 \%$ were not accepted and in such cases RNA extraction was repeated.

\subsection{Nested RT-PCR and cloning}

Reverse transcription (RT) was performed by adding $5 \mu$ l of extracted RNA to $3.9 \mu \mathrm{l}$ molecular biology grade water containing 500 ng of random hexamers (Promega, UK). The mixture was heated at $70^{\circ} \mathrm{C}$ for 5 minutes, chilled on ice, and then added to $6.1 \mu 1$ of reaction mix containing, as final concentrations, $10 \mathrm{mM}$ Tris- $\mathrm{HCl}(\mathrm{pH}=8.3), 50 \mathrm{mM} \mathrm{KCl,} 5$ mM of $\mathrm{MgCl}_{2}, 1 \mathrm{mM}$ of dNTPs, $20 \mathrm{U}$ of RNasin and $50 \mathrm{U}$ of Moloney murine leukemia virus reverse transcriptase (Applied Biosystems, Foster City, CA). The RT protocol involved incubation for $10 \mathrm{~min}$ at $23^{\circ} \mathrm{C}$, followed by $60 \mathrm{~min}$ at $37^{\circ} \mathrm{C}$ and inactivation at $95^{\circ} \mathrm{C}$ for $5 \mathrm{~min}$. Fifteen microliters of cDNA was added to $35 \mu \mathrm{l}$ of the PCR mixture, yielding a total of $50 \mu \mathrm{l}$ of a reaction mixture consisting of $10 \mathrm{mM}$ Tris- $\mathrm{HCl}(\mathrm{pH}=8.3), 50$ mM KCl, 1.5 mM MgCl $2,0.2$ mM dNTPs, 20 pmol of each primer, and 1U Ampli Taq polymerase. The primers (G1, G2, SM31) used in the first round of PCR were those described by (Green et al., 1998). One microliter of the first round PCR product was added to $49 \mu \mathrm{l}$ of the PCR mastermix containing $10 \mathrm{mM}$ Tris- $\mathrm{HCl}(\mathrm{pH}=8.3), 50 \mathrm{mM} \mathrm{KCl}, 1.5 \mathrm{mM}$ $\mathrm{MgCl}_{2}, 0.2 \mathrm{mM}$ dNTPs, $1 \mathrm{U}$ Ampli Taq polymerase, and 20 pmol of each primer (Ando, E3 for NoV GI and NI and E3 for NoV GII). In the nested PCR, previously described primers were used: Ando (Maguire et al., 1999), E3, and NI (Green et al., 1998). The nested PCR was carried out in separate tubes for NoV GI and NoV GII. The thermocycling format used in both rounds of PCR was as follows: an initial denaturation at $94^{\circ} \mathrm{C}$ for $2 \mathrm{~min}$; 30 
amplification cycles with denaturation at $95^{\circ} \mathrm{C}$ for $1 \mathrm{~min}$, annealing at $40^{\circ} \mathrm{C}$ for $1 \mathrm{~min}$, and extension at $72^{\circ} \mathrm{C}$ for $1 \mathrm{~min}$; and a final extension of $72^{\circ} \mathrm{C}$ for $10 \mathrm{~min}$. The amplification products were examined by gel electrophoresis ( $2 \%$ agarose) and molecular weights were determined by comparison with 25 bp DNA ladder (Invitrogen, Carlsbad, CA). The nested PCR products (113 bp for NoV GI, 112b p for NoV GII) were purified using CHROMA SPIN $^{\mathrm{TM}}$ columns (Unitech, Dublin, Ireland) and then cloned into the pGEM®-T Easy Vector System (Promega, UK). Transformation of bacterial cells and growth on agar plates was performed according to the manufacturer's instructions. Five white colonies per plate were analysed for the presence of the correct insertion size by PCR with a reaction mixture consisting of $10 \mathrm{mM}$ Tris-HCl (pH=8.3), $50 \mathrm{mM} \mathrm{KCl,} 1.25 \mathrm{mM} \mathrm{MgCl}_{2}, 0.2 \mathrm{mM}$ dNTPs, 2.5 U Ampli Taq polymerase, and 50 pmol of each primer (pTAg forward and reverse). PCR consisted of a denaturation step at $96^{\circ} \mathrm{C}$ for $10 \mathrm{~min}$; 30 amplification cycles of $95^{\circ} \mathrm{C}$ for $1 \mathrm{~min}, 37^{\circ} \mathrm{C}$ for $1 \mathrm{~min}$ and $72^{\circ} \mathrm{C}$ for $1 \mathrm{~min}$; and an extension step of $72^{\circ} \mathrm{C}$ for $10 \mathrm{~min}$. When the target band was observed (311 bp and 312 bp for NoV GI and NoV GII respectively) using gel electrophoresis (2\% agarose), the PCR products were purified with ExoSAP-IT® (USB Corporation, Cleveland, OH) and sequenced in both directions with the pTAg primers.

\subsection{DNA sequencing and phylogenetic analysis}

The ABI PRISM BigDye Terminator v 3.1 Ready Reaction kit (Applied Biosystems, Foster City, CA) was used according to the manufacturer's protocol and the PCR products were purified by DyeEx 2.0 Spin kit (Qiagen, West Sussex, UK) to remove incorporated dye terminators. Nucleotide sequences of the partial polymerase region were aligned using ClustalW algorithm of the MegAlign (DNAstar, Inc., Madison, Wis. USA) software and 
compared with reference strains retrieved from GenBank. The genotype nomenclature of the reference strains has been adopted from the Norovirus genotyping tool (National Institute of Public health and the Environment, the Netherlands, http://www.rivm.nl/mpf/norovirus/typingtool). All identical sequences were grouped together and relabelled with an alphabetic letter (groupA-groupJ). Phylogenetic analysis was carried out using HKY85 as a model for nucleotide substitution and a phylogenetic tree was constructed by the neighbour-joining method using PAUP* version 4.0 (Swofford, 2003). The reliability of the generated tree was estimated by bootstrap analysis of 1000 resamplings using PAUP* and the tree was drawn using FigTree version 1.3.1

\subsection{Reference strains}

The reference strains of NoVs included in the phylogenetic analysis were obtained from GenBank and are as follows (accession numbers in brackets); GIV.2 Norovirus lion (EF450827), GI.I SRSVKY89 (L23828), GI.2 Southampton (L07418), GI.b WUG1 (AB081723), GI.4 Baltimore (AF414404), GI.4 Chiba (AB0428008), GI.6 Hesse (AF093797), GI.c SZUG1 (AB039774), GI.3 NLV (AY038598), GI.d Vesoul (EF529738), GI.a Desert Shield (U04469), GI.f Otofuke (AB187514), GI.e Chatellerault (EF529737), GII.k OC96065 (AF315813), GII.18 Swine (AY823304), GII.d Hokkaido (AB212306), GII.15 Hiroshima (AB360387), GII.6 Saitama (AB039778), GII.2 Melksham (X81879), GII.f Human (AY682550), GII.1 Hawaii (U07611), GII.e HU2007JP (AB434770), GII.h OC97007 (AB089882), GII.5 MOH (AF397156), GII.c Snow Mountain (AY134748), GII.17 Briancon870 (EF529741), GII.3 Toronto (U02030), GII.b Pont de Roide (AY68259), GII.j E3 (AY682552), GII.g Goulburn Valley (DQ379714), GII.a Arg320 (AF190817), GII.12 HUMAN5017JPN (EU187437), GII.4 Bristol (X76716), GII.4 2006b 
(EF126966), GII.4 2006a (EF187497), GII.4 2004 (AB294785), and GII.4 2008

(AB491291).

\subsection{Statistical analysis}

Samples that were determined negative by RT-qPCR for a particular norovirus genogroup were scored 10 genome copies $\mathrm{g}^{-1}$ DT for that genogroup (half the LOD). The AndersonDarling test for normal distribution was applied to each data set and the NoV concentrations in oysters were logarithmically (base 10) transformed to achieve a normal distribution. Minitab statistical software version 16 (Minitab Inc., State College, PA) was used for the data analysis. 


\section{Results}

\subsection{NoV concentrations in oysters}

NoV (GI or GII) was detected in $95.6 \%(n=22)$ of the oyster samples analysed $(n=23)$ over the study period with total NoV (GI and GII) concentrations in positive oysters ranging from 97 to 20,080 genome copies $\mathrm{g}^{-1}$ DT. NoV concentrations in oysters demonstrated a strong seasonal trend. The mean concentration of total NoV in oysters during both winter periods (October-March) was 4,365 genome copies $\mathrm{g}^{-1}$ DT (range 363 to 20,080) compared with the mean concentration of 193 genome copies $\mathrm{g}^{-1}$ (range $<$ LOD to 4,060) in oysters analysed during the two summer periods (April to September). This difference was found to be statistically significant using a two tail unpaired t-test $(\mathrm{p}<0.001)$. The mean concentration of total NoV was 960 genome copies $\mathrm{g}^{-1}$ DT higher in the second year (October 2008/September 2009) of the study than in the first year (October 2007/September 2008).

For the entire study, the mean concentrations of NoV GI and NoV GII detected in oysters were 1568 and 1837 genome copies g $^{-1}$ DT respectively (Fig. 1). The NoV GI concentrations detected in oysters differed significantly between the first and second year $(p=0.046)$. This difference was pronounced during the winter months and in the winter of 2008/09 the mean NoV GI concentration in oysters was 5,713 (range from 1,020 to 15,100) genome copies $\mathrm{g}^{-1}$ DT compared to just 211 genome copies $\mathrm{g}^{-1}$ DT in the winter of 2007/08. This difference was highly significant $(\mathrm{p}<0.001)$. No difference in NoV GI concentrations was detected between the two years during the summer period with the mean concentrations of $<\mathrm{LOD}$ and 70 genome copies $\mathrm{g}^{-1} \mathrm{DT}$ present in oysters during the summer of 2007 and 2008, respectively. In the winter of 2007/08, the mean concentration of NoV GII was 4,337 (range 353 to 6,910) compared with 1,765 (range 938 to 4,980) genome 
copies $\mathrm{g}^{-1}$ DT in the winter of 2008/09, but this difference was not statistically different. Mean concentrations of NoV GII detected in the summer of 2008 and 2009 were 912 and 179 genome copies $\mathrm{g}^{-1} \mathrm{DT}$, respectively, however these concentrations were not significantly different. Data from the Health Protection Surveillance Centre (HPSC) for the corresponding geographic region to the investigated area showed a peak in general community reports (not specifically food-related) of NoV gastroenteritis cases ( $n=71$ ) occurred in January 2008. The greatest concentrations of NoV in oysters were detected in the following month (February 2008). Conversely in the second year, the greatest concentrations of NoV in oysters were detected in November 2008 and preceded the peak number of NoV cases (n=99) in the community that occurred in February 2009.

\subsubsection{Phylogenetic analysis of oyster samples}

During the two-year sampling period, a variety of NoV genotypes were detected in oysters (Fig. 2). Of the 23 samples analysed, 15 samples were positive for NoV GI by RT-qPCR compared with 18 samples by nested RT-PCR. Three NoV GI genotypes were identified from all samples positive by nested RT-PCR (Fig. 2). NoV GI.4 was most frequently detected, present in $88.9 \%$ of the GI positive samples, followed by GI.3 (33.3\%) and GI.2 (11.1\%). NoV GI.2 was only identified in the first year of the study, whereas GI.3 and GI.4 were detected in both years.

Of the 23 samples analysed, 22 samples were positive using NoV GII RT-qPCR compared with 16 samples by nested RT-PCR. Five NoV GII genotypes were identified by nested RT-PCR (Fig 2). Genotype GII.4 was identified in 43.7\% of GII positive samples, followed by GII.b (37.5\%), GII.e (12.5\%), GII.2 (6.2\%) and GII.12 (6.2\%). NoV GII.b was detected consistently from January to April 2008 and was the most prevalent genotype detected 
during the first year, whereas GII.4 was detected more frequently during the second year. NoV GII.2 and GII.12 were detected intermittently throughout the study period. Two variants of GII.4 were prevalent: 2006b and 2008. In November and December 2008 NoV GII.e genotype was detected and was found to have 100\% identity to reference strain GII.e (AB434770).

Of all the samples analysed $(n=23)$ multiple NoV genotypes were found in $69.6 \%(n=16)$ of the oyster samples. For instance, NoV GI.4, GII.4 2006b and GII.e were identified in oysters sampled in November 2008. 


\section{Discussion}

We analysed oysters from a production area over a two year study period, which had previously been linked to outbreaks of NoV illness and was closed for harvesting. Despite this closure, ongoing E. coli monitoring of the harvest area indicated that it was compliant with a category B classification prescribed under EU regulation 854/2004 (Anonymous, 2004). Shellfish products harvested from category B areas may be placed on the market for human consumption following treatment such as depuration or relaying so as to meet category A requirements $\left(<230\right.$ E. coli $\left.100 \mathrm{~g}^{-1}\right)$. Significant concentrations of NoV were detected in the majority of oyster samples tested over the two years of this study, particularly during the winter months. Total NoV concentrations greater than 100 genome copies $\mathrm{g}^{-1}$ DT were detected in $82.6 \%(\mathrm{n}=19)$ and concentrations greater than 1000 genome copies $\mathrm{g}^{-1} \mathrm{DT}$ were detected in $52.2 \%(\mathrm{n}=12)$ of all the samples. While post harvest treatment, such as depuration, can efficiently reduce $E$. coli concentrations as currently practiced, it does not eliminate viruses and outbreaks of illness can still occur (Doré et al., 2010; Le Guyader et al., 2006). It has been demonstrated that low concentrations of NoV present in oysters do not necessarily result in gastroenteritis when consumed. (Lowther et al., 2012) suggest that oysters containing total NoV concentrations of $<100$ genome copies $\mathrm{g}^{-1}$ DT represent a low health risk for consumers. Relatively high concentrations of NoV, $>1000$ genome copies $\mathrm{g}^{-1} \mathrm{DT}$, may be responsible for a higher incidence of NoV illness (Doré et al., 2010).

This study demonstrates that significant concentrations of NoV were present in oysters in the harvest area, despite compliance with category B health status. It is unlikely that post harvest treatment would reduce NoV contamination present in oysters during the winter months (mean concentration 6,013 genome copies $\mathrm{g}^{-1} \mathrm{DT}$ ) to safe concentrations. In 
combination with the history of illness associated with oysters previously harvested from this area, the data demonstrates the inadequacy of the current reliance on $E$. coli monitoring alone to control risks associated with oyster consumption. Furthermore, it demonstrates the potential value of NoV monitoring using RT-qPCR as an effective control to prevent oysters with significant concentrations of NoV from being placed on the market for consumption.

Total NoV contamination in oysters demonstrated a clear seasonal trend with elevated concentrations occurring during the winter months and is consistent with previous studies (Formiga-Cruz et al., 2002; Le Guyader et al., 2000; Lowther et al., 2008). The seasonal peak of NoV in oysters is probably due to the discharge of higher concentrations of NoV from WWTPs at this time due to peak community infections coupled with environmental factors such as lower temperature and decreased solar irradiation. It has been shown that enteric virus indicators can survive for prolonged periods of time at lower temperatures (Duizer et al., 2004; Sinton et al., 1999) and they are more rapidly inactivated when exposed to elevated doses of sunlight (Sinton et al., 1999). In addition, virus concentrations are reduced more rapidly at higher water temperatures (Doré et al., 1998; Doré et al., 2000). In this study, total NoV concentrations detected in oysters were higher in the winter of 2008/09 than in the winter of 2007/08. According to the HPSC reports for the corresponding geographic region in Ireland to where the study was conducted, more NoV gastroenteritis cases were notified in the winter season 2008/09 than in the previous winter (Cloak et al., 2009). In the second year of this study, peak NoV cases in the local community occurred after the increase in total NoV concentrations in oysters. This is consistent with another study that showed an increase in NoV concentrations in wastewaters prior to a peak in NoV cases in the community (da Silva et al., 2007). In our 
study, it is possible that the shellfish harvest area is impacted by a number of WWTPs and increased NoV concentrations in oysters can precede the clinical notifications in the corresponding region of Ireland.

Interestingly, NoV GI concentrations in oysters differed significantly between years unlike NoV GII that was detected at comparable concentrations in both years of this study. NoV GI concentrations were greater than NoV GII concentrations in the second year and may be indicative of increased NoV GI infections occurring in the population at this time. A higher incidence of NoV gastroenteritis was reported in the winter of 2008/09 than 2007/08 in Ireland (Cloak et al., 2009), England and Wales (HPA, 2012), and Belgium (Mathijs, 2011). No clinical data is, however, available showing a significant increase in NoV GI notifications for the winter period of 2008/09. Although NoV GII is responsible for the vast majority of reported clinical cases, environmental samples contain a greater variety of NoV genotypes. A number of studies have demonstrated that the prevalence and concentrations of both NoV genogroups may differ in wastewaters (da Silva et al., 2007; Katayama et al., 2008; Kitajima et al., 2012; La Rosa et al., 2010). Other studies have demonstrated that they are present at similar concentrations to one another at the same time (Flannery et al., 2012; Lowther, 2011). It has been suggested that NoV GI is more resistant to the WWTP process than NoV GII (da Silva et al., 2007), and also more stable in the water environment (Lysen et al., 2009) and that these features may lead to increased concentrations of NoV GI in oysters. Recently, it has been demonstrated that NoV GI.1 binds to A-like carbohydrate structures in the digestive gland of oysters and that the expression of this ligand during the winter period can facilitate increased NoV GI accumulation (Maalouf et al., 2010). This disproportionate concentration of NoV GI detected in oysters compared to clinical 
notifications may be as a result of increased expression of the ligand during the winter of 2007/2008. However, it has not been demonstrated whether expression of this ligand varies between the winter seasons.

Amongst the genotypes identified in oysters, NoV GI.4 was detected most frequently. This finding is consistent with previous studies that detected NoV GI.4 in influent and effluent wastewaters in Japan (Iwai et al., 2009; Kitajima et al., 2012) and a river catchment in Spain (Pérez-Sautu et al., 2012). It has also been reported that NoV GI.4 was the most frequently identified genotype in a large gastroenteritis outbreak of suspected waterborne transmission in Northern Italy (Di Bartoloa et al., 2011) and in a large foodborne outbreak in which more than 200 people were affected by frozen raspberries in Finland (Maunula et al., 2009). (Verhoef et al., 2010) showed that NoV GI.4 along with GI.2 were more frequently detected in foodborne outbreaks than in those transmitted via person-to-person. NoV GI.4 may have some unique properties that allows for better persistence in the environment and possibly better accumulation in shellfish. NoV GI.2 and GI.3 were detected less frequently throughout the study than GI.4; however, they have been detected in shellfish-related outbreaks worldwide (David et al., 2007; Kageyama et al., 2004; Le Guyader et al., 2003; Nakagawa-Okamoto et al., 2009).

The second most frequently identified genotype in oysters was NoV GII.4, followed by NoV GII.b. In the first year of the study NoV GII.b was more prevalent in the oyster samples and was then replaced in the second year by NoV GII.4, especially the variant 2006b. NoV GII.b was first identified in a large multi-pathogen waterborne outbreak in France in 2000 (Gallay et al., 2006) and since then has been recognised in many foodborne and person-to-person outbreaks across Europe (Bon et al., 2005; Koopmans et al., 2003; 
Reuter et al., 2005). NoV GII.b was circulating in the Irish population between 2006 and 2007 and was responsible for paediatric outbreaks reported at that time (Waters et al., 2008). NoV GII.4 2006b variant was first identified in the summer of 2006 and became the dominant variant of GII.4 from October 2007 in Europe when the number of reported gastroenteritis outbreaks increased (Siebenga et al., 2009). In Ireland, NoV GII.4 2006b can be linked to three clusters of NoV infections involving 62 cases reported following pilgrimages to Lourdes in late September 2008 (Verhoef et al., 2008). From our study, NoV GII.4 2006b was the predominant variant of NoV GII.4 found in oysters and therefore probably the predominant variant circulating in the Irish population in this region during the winter of 2008/2009.

Phylogenetic analysis was carried out using the partial (<100 bp) polymerase gene of the NoV genome. While this fragment of the NoV genome allows NoV genotypes to be categorised, its usefulness to distinguish between NoV GII.4 variants is limited, especially those that exhibit high nucleotide similarity in the polymerase region (GII.4 2004 and GII.4 2008). Alternative primers, targeting the capsid N/S domain of the NoV genome, may be useful in further elucidating the NoV genotype profiles in contaminated oyster samples (Nishida et al., 2003). We undertook further sequencing analysis targeting the capsid N/S domain in one sample from November 2008 which revealed a link between the GII.e polymerase and the GII.4 2007 capsid genotype (GII.e/GII.4 2007) (data not presented). This GII.e/GII.4 2007 variant has been simultaneously identified in Belgium as causing outbreaks in November 2008, December 2008 and February 2009 (Mathijs, 2011). As yet, data relating to the presence of the GII.e/GII.4 2007 variant in the Irish population is unavailable. 
This study demonstrates that RT-qPCR monitoring provides a better assessment of NoV contamination risk within shellfish harvest area than current bacteriological monitoring alone. In a recent opinion by the European Food Safety Authority, it was recommended that risk managers should consider establishing an acceptable limit for $\mathrm{NoV}$ in oysters to be placed on the market (EFSA, 2012). Until such a limit is established RT-qPCR monitoring in oyster harvest areas could be conducted to establish a more comprehensive approach to risk management than currently offered from $E$. coli monitoring alone. In addition, this study demonstrated contamination of oysters with multiple genotypes of GI and GII NoV. Although no direct evidence is presented in this paper, it is possible that the disproportionate detection of NoV GI genotypes in oysters compared to the dominance of NoV GII.4 in clinical reports may be because of asymptomatic infections in the community, better environmental survival or preferential accumulation in oysters associated with NoV GI genotypes or a combination of these factors.

\section{Acknowledgments}

We thank Dr. F.S Le Guyader, IFREMER for kindly providing us with the NoV GI and NoV GII plasmids used in the RT-qPCR. 


\section{References}

Anonymous. 2004. Regulation (EC) 854/2004 of the European Parliament and of the Council of 29 April 2004 laying down specific rules for the organisation of official controls on products of animal

origin intended for human consumption. . In: Communities, O.J.o.E., (Ed.), vol. L226. 83127.

Baker, K., Morris, J., McCarthy, N., Saldana, L., Lowther, J., Collinson, A., Young, M. 2010. An outbreak of norovirus infection linked to oyster consumption at a UK restaurant, February 2010. Journal of public health 33, 205-211.

Bon, F., Ambert-Balay, K., Giraudon, H., Kaplon, J., Le Guyader, S., Pommepuy, M., Gallay, A., Vaillant, V., de Valk, H., Chikhi-Brachet, R., Flahaut, A., Pothier, P., Kohli, E. 2005. Molecular epidemiology of caliciviruses detected in sporadic and outbreak cases of gastroenteritis in France from December 1998 to February 2004. Journal of Clinical Microbiology 43, 4659-4664.

Bull, R., Hansman, G., Clancy, L., Tanaka, M., Rawlinson, W., White, P. 2005. Norovirus recombination in ORF1/ORF2 overlap. Emerging Infectious Diseases 11, 1079-1085.

Butt, D., Aldridge, K., Sanders, C. 2004. Infections related to the Ingestion of Seafood Part 1: Viral and Bacterial Infections. The Lancet Infectious Diseases 4, 201-212.

Cloak, F., Foley, B., Cullen, G., Skally, M., Garvey, P., McKeown, P. 2009. Surveillance of infectious intestinal (IID), zoonotic and vectorborne disease, and outbreaks of inectious disease: Quarter 4-2007 to Quarter 3-2009. Health Protection Surveillance Centre.

Costafreda, M.I., Bosch, A., Pintó, R.M. 2006. Development, evaluation, and standardization of a real-time TaqMan reverse transcription-PCR assay for quantification of 
hepatitis A virus in clinical and shellfish samples. Applied and Environmental Microbiology 72, 3846-3855.

da Silva, A.K., Le Saux, J.C., Parnaudeau, S., Pommepuy, M., Elimelech, M., Le Guyader, F.S. 2007. Evaluation of removal of noroviruses during wastewater treatment, using realtime reverse transcription-PCR: different behaviours of genogroups I and II. Applied and Environmental Microbiology 73, 7891-7897.

David, S.T., McIntyre, L., MacDougall, L., Kelly, D., Liem, S., Schallié, K., McNabb, A., Houde, A., Mueller, P., Ward, P., Trottier, Y.L., Brassard, J. 2007. An outbreak of norovirus caused by consumption of oysters from geographically dispersed harvest sites, British Columbia, Canada, 2004. FOODBORNE PATHOGENS AND DISEASE 4, 349358.

Di Bartoloa, I., Moninia, M., Losiob, M.N., Pavonib, E., Lavazzab, A., Ruggeria, F.M. 2011. Molecular characterization of Norovirus and Rotavirus involved in a large outbreak of gastroenteritis in Northern Italy. Applied and Enviromental Microbiology 77, 55455548.

Doré, B., Keaveney, S., Flannery, J., Rajko-Nenow, P. 2010. Management of health risk associated with oysters harvested from a norovirus contaminated area, Ireland, February March 2010. EuroSurveillance 15, 1-5.

Doré, W.J., Henshilwood, K., Lees, D.N. 1998. The development of management strategies for control of virological quality in oysters. . Water Science and Technology 38, 29-35.

Doré, W.J., Henshilwood, K., Lees, D.N. 2000. Evaluation of F-specific RNA bacteriophage as a candidate human enteric virus indicator for bivalve molluscan shellfish. Applied and Environmental Microbiology 66, 1280-1285. 
Duizer, E., Bijkerk, P., Rockx, B., de Groot, D., Twisk, F., Koopmans, M. 2004.

Inactivation of Calciviruses. Applied and Environmental Microbiology 70, 4538-4543.

EFSA. 2012. Scientific Opinion on Norovirus (NoV) in oysters: methods, limits and control options. . EFSA Journal 10.

Flannery, J., Keaveney, S., Rajko-Nenow, P., O'Flaherty, V., Doré, W. 2012. Concentration of Norovirus during Wastewater Treatment and Its Impact on Oyster Contamination. Applied and Enviromental Microbiology 78, 3400-3406.

Formiga-Cruz, M., Tofino-Quesada, G., Bofill-Mas, S., Lees, D.N., Henshilwood, K., Allard, A.K., Conden-Hansson, A.-C., Hernroth, B.E., Vantarakis, A., Tsibouxi, A., Papapetropoulou, M., Furones, M.D., Girones, R. 2002. Distribution of human virus contamination in shellfish from different growing areas in Greece, Spain, Sweden, and the United Kingdom. Applied and Environmental Microbiology 68, 5990-5998.

Gallay, A., De Valk, H., Cournot, M., Ladeuil, B., Hemery, C., Castor, C., Bon, F., Mégraud, F., Le Cann, P., Desenclos, J.C., Team., O.I. 2006. A large multi-pathogen waterborne community outbreak linked to faecal contamination of a groundwater system, France, 2000. Clinical microbiology and infection 12, 561-570.

Green, J., Henshilwood, K., Gallimore, C.I., Brown, D., Lees, D.N. 1998. A nested reverse transcriptase PCR assay for detection of small round-structured viruses in environmentally contaminated molluscan shellfish. Applied and Environmental Microbiology 64, 858-863. Halliday, M.L., Kang, L.Y., Zhou, T.K., Hu, M.D., Pan, Q.C., Fu, T.Y., Huang, Y.S., Hu, S.L. 1991. An epidemic of hepatitis a attributable to the ingestion of raw clams in Shanghai, China. Journal of Infectious Diseases 164, 852-859. HPA. 2012. Laboratory reports of norovirus infections in England and Wales by month of report, 2000-2011 Health Proctection Agency. 
Huppatz, C., Munnoch, S., A.,, Worgan, T., Merritt, T., D.,, Dalton, C., Kelly, P.M., Durrheim, D.N. 2008. A norovirus outbreak associated with consumption of NSW oysters: implications for quality assurance systems. Communicable Diseases Intelligence 32, 88-91. Iwai, M., Hasegawa, S., Obara, M., Nakamura, K., Horimoto, E., Takizawa, T., Kurata, T., Sogen, S., Shiraki, K. 2009. Continuous presence of noroviruses and sapoviruses in raw sewage reflects infections among inhabitants of Toyama, Japan (2006 to 2008). Applied and Enviromental Microbiology 75, 1264-1270.

Jiang, X., Min Wang, Kening Wang, Mary K. Estes. 1993. Sequence and Genomic Organization of Norwalk Virus. Virology 195, 51-61.

Kageyama, T., Kojima, S., Shinohara, M., Uchida, K., Fukushi, S., Hoshino, F.B., Takeda, N., Katayama, K. 2003. Broadly reactive and highly sensitive assay for Norwalk-like viruses based on real-time quantitative reverse transcription-PCR. Journal of Clinical Microbiology 41, 1548-1557.

Kageyama, T., Shinohara, M., Uchida, K., Fukushi, S., Hoshino, F.B., Kojima, S., Takai, R., Oka, T., Takeda, N., Katayama, K. 2004. Coexistence of multiple genotypes, including newly identified genotypes, in outbreaks of gastroenteritis due to norovirus in Japan. Journal of Clinical Microbiology 42, 2988-2995.

Kaplan, J., E., , Feldman, R., Campbell, D., S., , Lookabaugh, C., Gary, G., W. 1982. The frequency of a Norwalk-like pattern of illness in outbreaks of acute gastroenteritis. The American Journal of Public Health 72, 1329-1332.

Katayama, H., Haramoto, E., Oguma, K., Yamashita, H., Tajima, A., Nakajima, H., Ohyaki, S. 2008. One-year monthly quantitative survey of noroviruses, enteroviruses, and adenoviruses in wastewater collected from six plants in Japan. Water Research 42, 14411448. 
Kitajima, M., Haramoto, E., Phanuwan, C., Katayama, H., Furumai, H. 2012. Molecular detection and genotyping of human noroviruses in influent and effluent water at a wastewater treatment plant in Japan. Journal of Applied Microbiology 112, 605-613. Koopmans, M., Vennema, H., Heersma, H., van Strien, E., van Duynhoven, Y., Brown, D., Reacher, M., Lopman, B., Viruses., E.C.o.F. 2003. Early identification of common-source foodborne virus outbreaks in Europe. Emerging Infectious Diseases 9, 1136-1142.

Kroneman, A., Verhoef, L., Harris, J., Vennema, H., Duizer, E., van Duynhoven, Y., Gray, J., Iturriza, M., Bottiger, B., Falkenhorst, G., Johnsen, C., von Bonsdorff, C.H., Maunula, L., Kuusi, M., Pothier, P., Gallay, A., Schreier, E., Hohne, M., Koch, J., Szucs, G., Reuter, G., Krisztalovics, K., Lynch, M., McKeown, P., Foley, B., Coughlan, S., Ruggeri, F.M., Di Bartolo, I., Vainio, K., Isakbaeva, E., Poljsak-Prijatelj, M., Grom, A.H., Mijovski, J.Z., Bosch, A., Buesa, J., Fauquier, A.S., Hernandez-Pezzi, G., Hedlund, K.O., Koopmans, M. 2008. Analysis of integrated virological and epidemiological reports of norovirus outbreaks collected within the Foodborne Viruses in Europe Network from 1 July 2001 to 30 June 2006. Journal of Clinical Microbiology 46, 2959-2965.

La Rosa, G., Iaconelli, M., Pourshaban, M., Muscillo, M. 2010. Detection and molecular characterization of noroviruses from five sewage treatment plants in central Italy. Water Research 44, 1777-1784.

Le Guyader, F., Haugarreau, L., Miossec, L., Dubois, E., Pommepuy, M. 2000. Three-year study to assess human enteric viruses in shellfish. Applied and Environmental Microbiology 66, 3241-3218.

Le Guyader, F.S., Bon, F., DeMedici, D., Parnaudeau, S., Bertone, A., Crudeli, S., Doyle, A., Zidane, M., Suffredini, E., Kohli, E., Maddalo, F., Monini, M., Gallay, A., Pommepuy, M., Pothier, P., Ruggeri, F.M. 2006. Detection of multiple noroviruses associated with an 
international gastroenteritis outbreak linked to oyster consumption. Journal of Clinical Microbiology 44, 3878-3882.

Le Guyader, F.S., Krol, J., Ambert-Balay, K., Ruvoen-Clouet, N., Desaubliaux, B., Parnaudeau, S., Le Saux, J.C., Ponge, A., Pothier, P., Atmar, R.L., Le Pendu, J. 2010. Comprehensive Analysis of a Norovirus-Associated Gastroenteritis Outbreak, from the Environment to the Consumer. Journal of Clinical Microbiology 48, 915-920.

Le Guyader, F.S., Neill, F.H., Dubois, E., Bon, F., Loisy, F., Kholi, E., Pommepuy, M., Atmar, R.L. 2003. A semiquantitative approach to estimate Norwalk-like virus contamination of oysters. International Journal of Food Microbiology 87, 107-112.

Le Guyader, F.S., Parnaudeau, S., Schaeffer, J., Bosch, A., Loisy, F., Pommepuy, M., Atmar, R.L. 2009. Detection and Quantification of Noroviruses in Shellfish. Applied and Environmental Microbiology 75, 618-624.

Lees, D. 2000. Viruses and bivalve shellfish. International Journal of Food Microbiology 59, 81-116.

Lees, D., TAG4, C.W. 2010. International Standardisation of a Method for Detection of Human Pathogenic Viruses in Molluscan Shellfish. Food and Environmental Virology 2, $146-155$.

Loisy, F., Atmar, R.L., Guillon, P., Le Cann, P., Pommepuy, M., Le Guyager, F.S. 2005. Real-time RT-PCR for norovirus screening in shellfish. Journal of Virological Methods 123, $1-7$.

Lopman, B., Armstrong, B., Atchison, C., Gray, J.J. 2009. Host, weather and virological factors drive norovirus epidemiology: time series analysis of laboratory surveillance data in England and Wales. PLos ONE 4, 1-10. 
Lopman, B.A., Reacher, M.H., Vipond, I.B., Hill, D., Perry, C., Halladay, T., Brown, D.W., Edmunds, W.J., Sarangi, J. 2004. Epidemiology and cost of nosocomial gastroenteritis, Avon, England, 2002-2003. Emerging Infectious Diseases 10, 1827-1834. Lowther, J.A. 2011. Invetsigation into the levels of norovirus in influent and treated wastewater samples from a sewage treatment works. Food Standards Agency. Lowther, J.A., Gustar, N.E., Hartnell, R.E., Lees, D.N. 2012. Comparison of norovirus RNA levels in outbreak-related oysters with background environmental levels. Journal of Food Protection 75, 389-393.

Lowther, J.A., Henshilwood, K., Lees, D.N. 2008. Determination of norovirus contamination in oysters from two commercial harvesting areas over an extended period, using semiquantitative Real-Time reverse transcription PCR. Journal of Food Protection 71, 1427-1433.

Lysen, M., Thorhagen, M., Brytting, M., Hjertqvist, M., Andersson, Y., Hedlund, K.O. 2009. Genetic Diversity among Food-Borne and Waterborne Norovirus Strains Causing Outbreaks in Sweden. Journal of Clinical Microbiology 47, 2411-2418.

Maalouf, H., Zakhour, M., Le Pendu, J., Le Saux, J.C., Atmar, R.L., Le Guyader, F.S. 2010. Distribution in tissue and seasonal variation of norovirus genogroup I and II ligands in oysters. Applied and Environmental Microbiology 76, 5621-5630.

Maguire, A., Green, J., Brown, D., Desselberger, U., Gray, J. 1999. Molecular epidemiology of outbreaks of gastroenteritis associated with small round-structured viruses in East Anglia, United Kingdom, during the 1996-1997 season. Journal of Clinical Microbiology 37, 81-89. 
Mathijs, E., Denayer, S., Palmeira, L., Botteldoorn, N., Scipioni, A., Vanderplasschen, A., Thiry, E., and Dierick K. . 2011. Novel norovirus recombinants and GII.4 sub-lineages associated with outbreaks between 2006 and 2010 in Belgium. Virology Journal 8. Maunula, L., Roivainen, M., Keranen, M., Makela, S., Soderberg, K., Summa, M., Von Bonsdorff, C.H., Lappalainen, M., Korhonen, T., Kuusi, W., Niskanen, T. 2009. Detection of human Norovirus from Frozen Raspberries in a Cluster of Gastroenteritis Outbreaks EuroSurveillance, 1-3.

Nakagawa-Okamoto, R., Arita-Nishida, T., Toda, S., Kato, H., Iwata, H., Akiyama, M., Nishio, O., Kimura, H., Noda, M., Takeda, N., Oka, T. 2009. Detection of Multiple Sapovirus Genotypes and Genogroups in Oyster-Associated Outbreaks. Japanese journal of medical science \& biology 62, 63-66.

Nishida, T., Kimura, H., Saitoh, M., Shinohara, M., Kato, M., Fukuda, S., Munemura, T., Mikami, T., Kawamoto, A., Akiyama, M. 2003. Detection, quantification, and phylogenetic Analysis of Noroviruses in Japanese Oysters. Applied and Environmental Microbiology 69, 5782-5786.

Pérez-Sautu, U., Sano, D., Guix, S., Kasimir, G., Pintó, R.M., Bosch, A. 2012. Human norovirus occurrence and diversity in the Llobregat river catchment, Spain. Environmental microbiology 14, 494-502.

Pintó, R.M., Costafreda, M.I., Bosch, A. 2009. Risk Assessment in Shellfish-Borne Outbreaks of Hepatitis A. Applied and Environmental Microbiology 75, 7350-7355. Reuter, G., Krisztalovics, K., Vennema, H., Koopmans, M., Szucs, G. 2005. Evidence of the etiological predominance of norovirus in gastroenteritis outbreaks--emerging newvariant and recombinant noroviruses in Hungary. Journal of Medical Virology 76, 598-607. 
Richards, G.P. 1985. Outbreaks of shellfish-associated enteric virus illness in the United States: requisite for development of viral guidelines Journal of Food Protection 48, 815823.

Siebenga, J.J., Vennema, H., Zheng, D.P., Vinje, J., Lee, B.E., Pang, X.L., Ho, E.C.M., Lim, W., Choudekar, A., Broor, S., Halperin, T., Rasool, N.B.G., Hewitt, J., Greening, G.E., Jin, M., Duan, Z.J., Lucero, Y., O'Ryan, M., Hoehne, M., Schreier, E., Ratcliff, R.M., White, P.A., Iritani, N., Reuter, G., Koopmans, M. 2009. Norovirus Illness Is a Global Problem: Emergence and Spread of Norovirus GII.4 Variants, 2001-2007. Journal of Infectious Diseases 200, 802-812.

Sinton, L.W., Finlay, R.K., Lynch, P.A. 1999. Sunlight Inactivation of Fecal Bacteriophages and Bacteria in sewage-Polluted Seawater. Applied and Environmental Microbiology 65, 3605-3613.

Svraka, S., Duizer, E., Vennema, H., de Bruin, E., van de Veer, B., Dorresteijn, B., Koopmans, M. 2007. Etiological role of viruses in outbreaks of acute gastroenteritis in The Netherlands from 1994 through 2005. Journal of Clinical Microbiology 45, 1389-1394. Swofford, D.L. 2003. PAUP*. Phylogenetic Analysis Using Parsimony (*and Other Methods). Version 4. Sinauer Associates, Sunderland, Massachusetts.

Verhoef, L., Vennema, H., Siebenga, J., Swaan, C., Isken, L., Koopmans, M., Balay, K., Pothier, P., McKeown, P., van Dijk, G., Capdepon, P., Delmas, G. 2008. İmport of norovirus infections in The Netherlands and Ireland following pilgrimages to Lourdes, 2008 - Preliminary report. EuroSurveillance 13.

Verhoef, L., Vennema, H., van Pelt, W., Lees, D., Boshuizen, H., Henshilwood, K., Koopmans, M. 2010. Use of Norovirus Genotype Profiles to Differentiate Origins of Foodborne Outbreaks. Emerging Infectious Diseases 16, 617-624. 
Waters, A., Dunford, L., Tuite, G., Connell, J., Dooley, S., Foley, B., McKeown, P., Hall, W.W., Coughlan, S. 2008. Significant Prevalence and Genetic Diversity of Norovirus Infection in Irish Children. Pediatric Research 64, 312-316.

Zheng, D.P., Ando, T., Fankhauser, R., Beard, R., Glass RI., Monroe SS. 2006. Norovirus classification and proposed strain nomenclature. Virology 346, 1580-1583. 
Fig 1 Monthly clinical cases of NoV gastroenteritis and concentrations and genotypes of NoV detected in oysters. RT-qPCR results for NoV GI (black bars) and NoV GII (striped bars) are expressed in genome copies $\mathrm{g}^{-1} \mathrm{DT}$. Nested RT-PCR results for NoV GI (black blocks) and NoV GII (striped blocks) are shown in the grid below the graph.. The LOD of the RT-qPCR is represented by solid line; $(\times)$ represents no sample and $(\mathrm{N})$ represents samples negative from the nested RT-PCR. NoV clinical cases reported each month provided by HPSC are indicated by the dotted line (Cloak et al., 2009).

Fig 2 Phylogenetic trees for NoV sequences detected in oysters. Phylogenetic tree for NoV GI (on the left) and NoV GII (on the right) include bootstrap scores for branches shown as a percentage of 1000 replicates. The scale at the bottom represents genetic distances in nucleotide substitutions pre site. The name of sequence preceded by a small letter was used to distinguish between multiple NoV sequences obtained from a single sample. All identical sequences were grouped together and relabeled with a capital letter (groupAgroupJ). The GenBank accession numbers of NoV reference strains are given in section 2.6. 
<smiles>C#CC#C</smiles> 



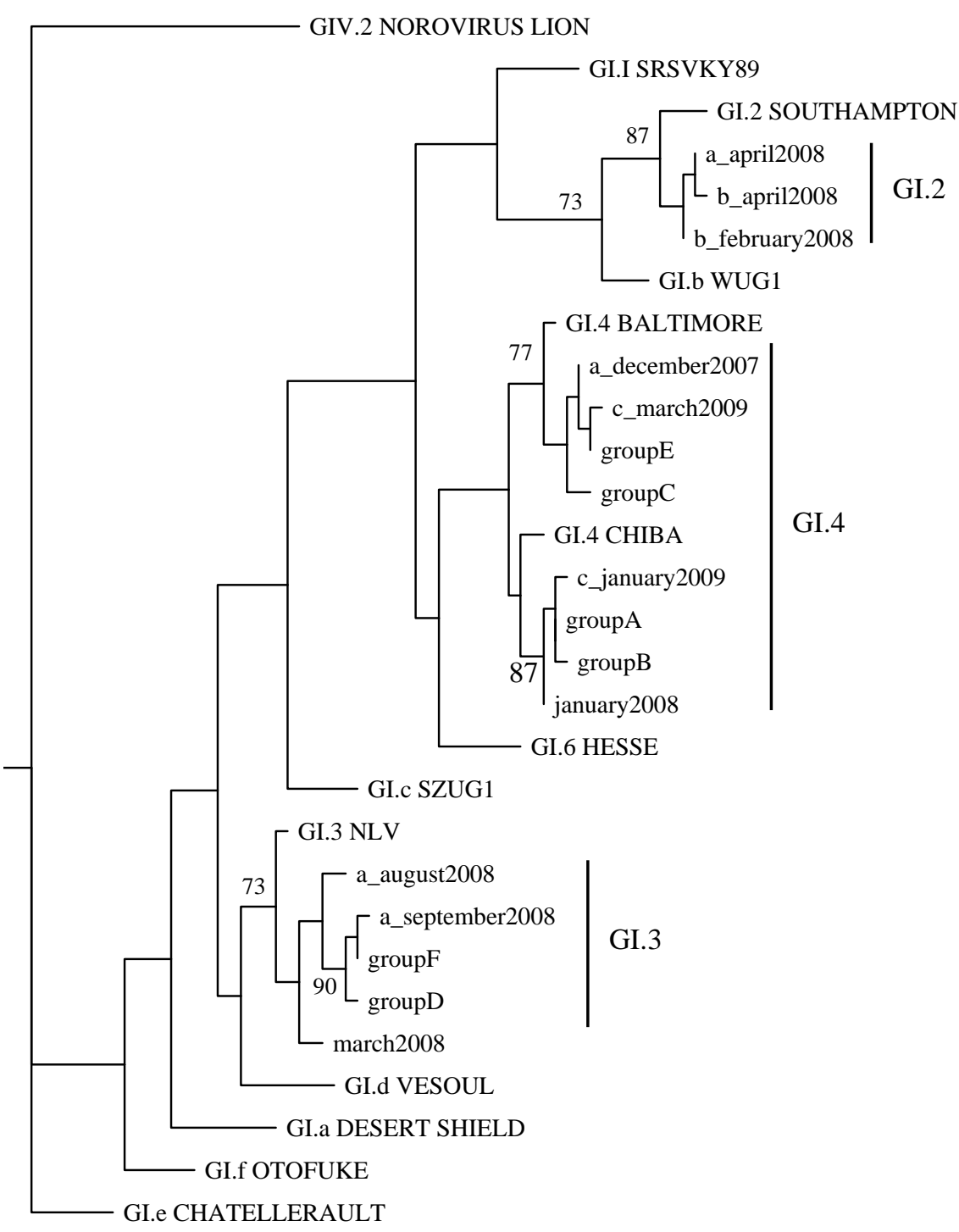

$\overline{3.0}$

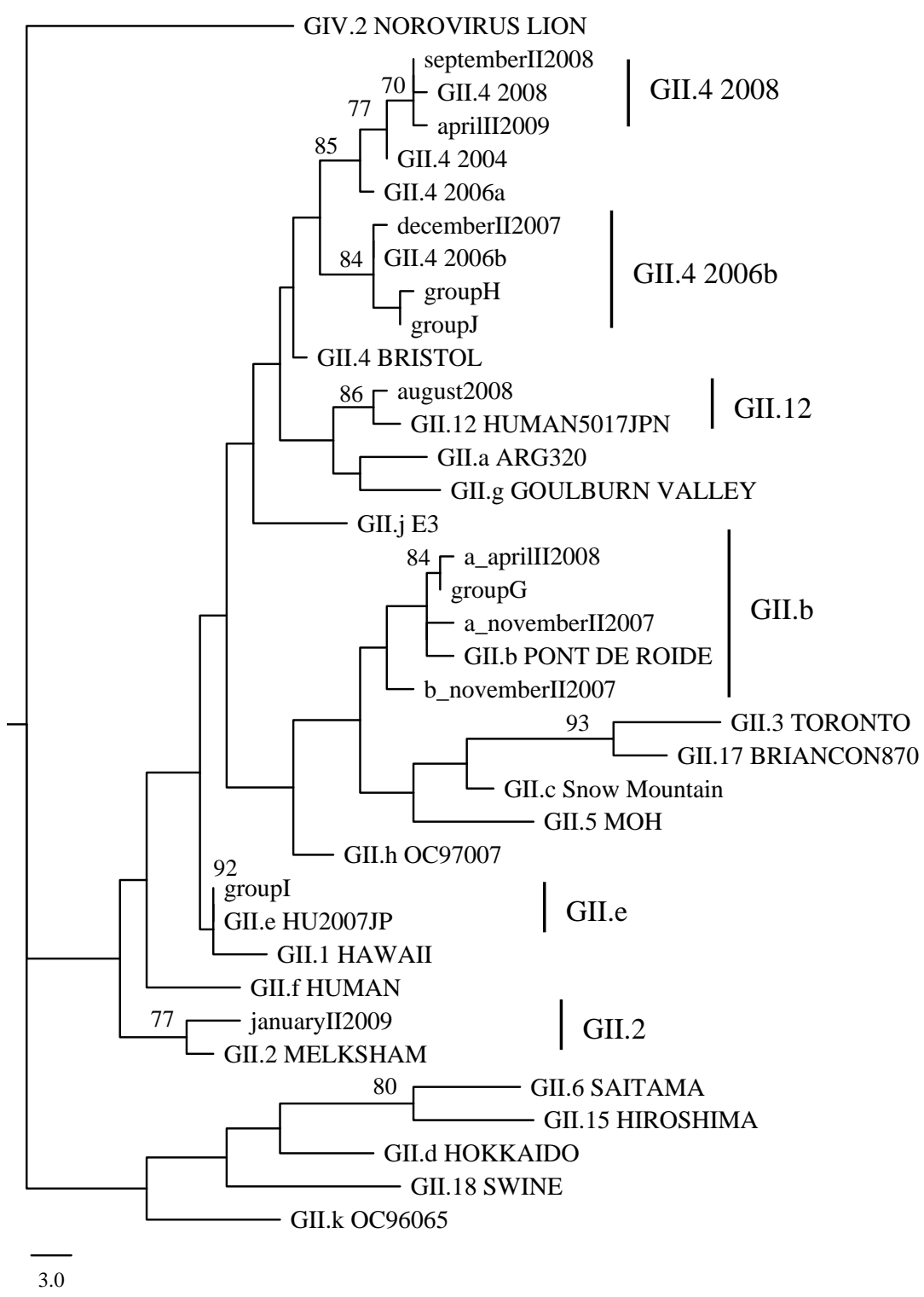

